\title{
APAKAH PT REKAYASA INDUSTRI MEREKAYASA LAPORAN KEUANGAN? SEBUAH ANALISIS MENGGUNAKAN BENEISH M- SCORE
}

\author{
Kodirin 1) \\ 1) kodirin@pknstan.ac.id, Politeknik Keuangan Negara STAN
}

\begin{abstract}
This study aims to test whether there is an indication of manipulation in the financial statements of PT Rekayasa Industri (Rekind) in 2018 or not. This research is descriptive using secondary data. The object of this research is the 2018 Rekind comparative financial Report available on the Record website. Rekind has experienced financial difficulties due to disputes with PT Amara Panca Utama regarding the Project of the Banggai Ammonia Plant. The method used to measure manipulation potential is the Beneish M-Score model. Rekind allegedly conducted manipulation to "improve" financial statements in 2018 as a way out of financial difficulties that hit. The results of the analysis concluded that the account was indicated to carry out manipulation for the financial statements of 2018. This conclusion was taken based on the value of the Beneish M-score of the 2018 financial statement of 1.49, greater than the benchmark value, -222. This finding is in line with the research before which concludes that the company conducts financial statements manipulation as one way to cover the condition of a bad company due to experiencing financial difficulties and that financial distress influencing the integrity of financial statements negatively. There are two indexes that are indicated to be manipulated, namely GMI and TATA; three indexes indicated that are not manipulated, namely DSRI, AQI, and SGAI; and three indexes that are on gray area, SGI, DEPI, and LVGI.
\end{abstract}

Keywords: PT Rekayasa Industri, Financial Distess, Manipulation, Financial Statementts, Beneish M-Score

\begin{abstract}
Abstrak
Penelitian ini bertujuan untuk menguji apakah terdapat indikasi rekayasa pada laporan keuangan PT Rekayasa Industri (Rekind) tahun 2018 atau tidak. Penelitian ini bersifat deskriptif dengan menggunakan data sekunder. Objek penelitian ini adalah laporan keuangan komparatif Rekind tahun 2018 yang tersedia di website Rekind. Rekind mengalami kesulitan keuangan akibat perselisihan dengan PT Amara Panca Utama terkait proyek Banggai Ammonia Plant. Metode yang digunakan untuk mengukur potensi rekayasa adalah model Beneish M-Score. Rekind diduga melakukan rekayasa untuk "memperbaiki” laporan keuangan tahun 2018 sebagai jalan keluar atas kesulitan keuangan yang menerpa. Hasil analisis menyimpulkan bahwa Rekind terindikasi melakukan rekayasa atas laporan keuangan tahun 2018. Kesimpulan ini diambil berdasarkan nilai Beneish M-Score laporan keuangan Rekind tahun 2018 sebesar -1,49, lebih besar daripada nilai patokan, -2,22. Temuan ini sejalan dengan penelitian sebelum yang menyimpulkan bahwa perusahaan melakukan rekayasa laporan keuangan sebagai salah satu cara untuk menutupi kondisi perusahaan yang buruk akibat mengalami kesulitan keuangan dan financial distress berpengaruh negatif terhadap integritas laporan keuangan. Terdapat dua indeks yang terindikasi telah direkayasa yaitu GMI dan TATA; tiga rasio yang terindikasi tidak direkayasa yaitu DSRI, AQI, dan SGAI; dan tiga rasio yang berada pada grey area yaitu SGI, DEPI, dan LVGI.
\end{abstract}

Kata Kunci: PT Rekayasa Industri, Kesulitan Keuangan, Rekayasa, Laporan Keuangan, Beneish M-Score

\section{PENDAHULUAN}

PT Rekayasa Industri (Rekind) adalah salah satu anak perusahaan PT Pupuk Indonesia. EPC (manipulation, procurement, dan construction) atau rancang bangun industri menjadi sektor usaha Rekind. Beberapa proyek industri skala besar telah dibuat oleh Rekind antara lain pabrik petrokimia dan pabrik pupuk. Pemegang saham mayoritas Rekind adalah PT Pupuk Indonesia (90,6\%). Pemegang kepemilikan minoritasnya adalah PT Pupuk Kalimantan Timur dan Negara Republik Indonesia. Hanya ada satu perusahaan EPC nasional yang murni dimiliki oleh bangsa Indonesia, tanpa kepemilikan asing, yaitu Rekind. Bangsa Indonesia diharapkan tidak tergantung pada kontraktor asing dalam pengembangan industri skala besar dengan beroperasinya Rekind sejak tahun 1981. Selain di dalam negeri, hasil pekerjaan Rekind juga ada di beberapa negara di Asia Tenggara. Nama Rekind termasuk dalam 250 kontraktor EPC Global versi Majalah Manipulation News Record (ENR) edisi bulan Agustus tahun 2016, 


\section{JURNALKU}

Volume 1 No. 4, Desember 2021

ASEAN Manipulation tahun 2018, dan Golden Valve Animation tahun 2018. Hal ini menjadi kebanggaan nasional.

Gatramagazine.com pada pertengahan bulan Februari tahun 2020 mewartakan perselisihan antara Rekind sebagai pihak kontraktor dan PT Panca Amara Utama (PAU) sebagai pemberi kontrak dalam pembangunan Banggai Ammonia Plant (BAP). Pabrik ini dibangun dengan skema EPC dan jasa commissioning. Nilai kontrak BAP lebih dari US\$500 juta dan waktu pengerjaan 2 tahun lebih. Sehari setelah perayaan Hari Ulang Tahun Kemerdekaan RI tahun 2018 uji kinerja pabrik dilakukan. Setelah lulus uji kinerja, BAP mulai beroperasi untuk memenuhi pesanan para pemesan. Namun terjadi perselisihan antara pihak kontraktor dan pihak pemberi kontrak. Kontraktor menuduh pemberi kontrak secara sepihak telah mencairkan uang jaminan kontraktor sebesar lebih dari US\$50 juta atau setara lebih dari Rp800 miliar. Selain itu, uang retensi sekitar Rp700 miliar ditahan oleh pemberi kontrak padahal proyek sudah selesai dan sudah mulai beroperasi. Di samping itu, pemberi kontrak belum melunasi piutang sekitar Rp150 miliar dan persetujuan change order sekitar Rp350 miliar. Dalam kasus ini lebih dari Rp 2 triliun uang kontraktor yang masih ditahan oleh pemberi kontrak. Hal ini mengakibatkan Rekind kesulitan keuangan dan minta bantuan kepada perusahaan induknya. Di lain pihak, pemberi kontrak berkeras bahwa kontraktor tidak tepat waktu dalam menyelesaikan pabrik (Sianturi, 2020b). Terkait kisruh ini, Bisman Bhaktiar, Direktur Eksekutif Pusat Studi Hukum Energi \& Pertambangan (PUSHEP), menganggap ada rekayasa untuk menggelapkan uang negara (Sianturi, 2020a)

Rekayasa laporan laba rugi dan laporan posisi keuangan dijadikan solusi untuk "mempercantik" keadaan perusahaan yang tidak menggembirakan akibat permasalahan keuangan (Y. A. Nugroho, 2017). Simpulan ini didapatkan setelah dilakukan pengujian dengan sampel sekitar 100 perusahaan pabrikasi dalam negeri dalam rentang lima tahun sejak 2009. Haq et al (2017) menyimpulkan bahwa keandalan laporan laba rugi dan laporan posisi keuangan dipengaruhi secara negatif negatif oleh permasalahan keuangan atas kajian terhadap lebih dari 100 perusahaan pabrikasi yang melantai di bursa dalam rentang lima tahun sejak 2011. Dengan demikian dapat diduga bahwa Rekind yang mengalami kesulitan keuangan pada tahun 2018 melakukan rekayasa laporan laba rugi dan laporan posisi keuangan.

Ozcan (2018) menyatakan bahwa salah satu metode yang sangat efektif untuk mendeteksi rekayasa laporan keuangan adalah model Beneish M-Score. Ozcan (2018) mengukur kemampuan model Beneish dalam mendeteksi lebih dari 170 perusahaan yang terdaftar di Bursa Istambul yang merekayasa laporan keuangan dalam kurun waktu lebih dari 10 tahun sejak 2005. Hasil analisis menunjukkan bahwa model ini sangat efektif untuk memprediksi rekayasa laporan laba rugi dan laporan posisi keuangan. Hugo (2019) menguji kemampuan model Beneish M-Score dalam mendeteksi rekayasa laporan keuangan. Sampel yang digunakan adalah 100 perusahaan yang terdaftar di bursa efek Amerika Serikat yang melakukan rekayasa laporan keuangan dalam rentang 21 tahun sejak 1997. Hasil pengujian menunjukkan bahwa model ini terbukti efektif untuk mendeteksi adanya rekayasa laporan laba rugi dan laporan posisi keuangan. Alfian dan Triani (2018) meneliti kemampuan model Beneish M-Score untuk mendeteksi rekayasa laporan laba rugi dan laporan posisi keuangan lebih dari 50 perusahaan perekayasa yang menyimpang dari peraturan OJK dalam rentang 5 tahun mulai 2012 dan lebih dari 50 perusahaan non-perekayasa sebagai pembanding. Hasil penelitian memperlihatkan bahwa lebih dari setengah perusahaan perekayasa diklasifikasikan dengan benar dan $60 \%$ perusahaan non-perekayasa diklasifikasikan dengan benar.

Sejauh penelitian, belum ada yang menggunakan Beneish M-Score untuk mendeteksi apakah laporan keuangan Rekind terindikasi direkayasa atau tidak. Dalam penelitian ini akan dilakukan analisis apakah laporan laba rugi dan laporan posisi keuangan Rekind tahun 2018 terindikasi direkayasa atau tidak menggunakan model Beneish M-Score. Penelitian ini 


\section{JURNALKU}

Volume 1 No. 4, Desember 2021

bertujuan untuk mengetahui apakah laporan laba rugi dan laporan posisi keuangan Rekind tahun 2018 terindikasi direkayasa atau tidak. Hipotesis penelitian yang diajukan adalah Rekind merekayasa laporan laba rugi dan laporan posisi keuangan tahun 2018 mengingat kesulitan keuangan yang dialami sebagai akibat perselisihan dengan salah satu pemberi kontrak. Berbeda dengan penelitian yang dilakukan oleh Y.A. Nugroho (2017) dan Haq et al (2017) yang menggunakan banyak perusahaan sebagai sampel, penelitian ini fokus pada satu perusahaan saja. Berbeda dengan penelitian Ozcan (2018), Hugo (2019), dan Alfian dan Triani (2018) yang menggunakan perusahaa-perusahaan yang sudah terbukti melakukan rekayasa laporan keuangan sebagai objek penelitan, penelitian ini menggunakan satu perusahaan yang diduga telah melakukan rekayasa laporan keuangan.

\section{KAJIAN PUSTAKA}

Beneish (1999) mendefinisikan rekayasa laporan laba rugi sebagai tindakan manajer perusahaan membuat laporan laba rugi tidak sesuai dengan generally accepted accounting principles (GAAP) demi mendongkrak kinerja keuangan perusahaan. Beneish (1999) menciptakan sebuah model untuk mendeteksi rekayasa laporan laba rugi dan laporan posisi keuangan. Maccarthy (2017) melakukan kajian untuk menguji apakah Altman Z-Score dan Beneish M-Model dapat mendeteksi rekayasa laporan laba rugi dan laporan posisi keuangan Enron. Kajian tersebut menemukan indikasi rekayasa laporan laba rugi dan laporan posisi keuangan selama rentang waktu lima tahun sejak 1996. Maccarthy (2017) menemukan bahwa lebih baik menggunakan kedua model digunakan secara bersamaan daripada hanya Altman Zscore yang digunakan. Model Beneish M-Score digunakan oleh Nugroho (2020) untuk memperkirakan kemungkinan rekayasa laporan laba rugi dan laporan posisi keuangan PT Garuda Indonesia tahun 2018. Hasil analisisnya menyimpulkan bahwa terdapat kemungkinan rekayasa atas laporan laba rugi.

Penelitian ini mengikuti penelitian Maccarthy (2017) dan Nugroho (2020) dalam hal penggunaan model Beneish M-Score untuk memperkirakan apakah laporan keuangan suatu perusahaan direkayasa atau tidak. Lebih dalam dari analisis yang dilakukan oleh Maccarthy (2017) dan Nugroho (2020), penelitian ini menganalisis data akun-akun yang terkait dengan rasio-rasio keuangan yang diperkirakan telah dimanipulasi.

\section{METODE}

Penelitian ini bersifat deskriptif. Data sekunder digunakan dalam penelitian ini. Laporan keuangan komparatif Rekind tahun 2018 yang tersedia di website Rekind menjadi objek penelitian. Model Beneish M-Score digunakan untuk mengukur potensi rekayasa pada laporan keuangan komparatif Rekind tahun 2018. Terdapat delapan indeks keuangan yang digunakan oleh Beneish (1999) dengan penjelasan sebagai berikut:

- Days' sales in receivales index (DSRI)

DSRI adalah rasio days' sales in receivables tahun pertama rekayasa laba ditemukan (tahun t) terhadap days' sales in receivables tahun sebelumnya (tahun t-1). Indeks ini mengukur keseimbangan piutang dan pendapatan pada dua tahun yang berurutan. Peningkatan rasio days' sales in receivables yang signifikan bisa disebabkan oleh perubahan kebijakan penjualan kredit untuk meningkatkan penjualan. Namun, pembengkakkan piutang yang tidak proporsional dengan penjualan boleh jadi disebabkan oleh penggelembungan pendapatan. Dengan demikian kenaikan DSRI yang signifikan bisa diduga terkait dengan penggelembungan pendapatan.

- Gross margin index (GMI)

GMI merupakan rasio laba kotor tahun t-1 terhadap laba kotor tahun t. Nilai GMI lebih besar daripada 1 menunjukkan bahwa laba kotor tahun $\mathrm{t}$ lebih kecil daripada laba kotor 
tahun t-1. Ini merupakan sinyal negatif atas prospek perusahaan di masa yang akan datang. Perusahaan dengan prospek yang kurang baik diperkirakan lebih mungkin untuk melakukan rekayasa laporan laba rugi.

- Aset quality index (AQI)

Kualitas aset diukur dengan rasio noncurrent assets selain property, plant, and equipment (PPE) terhadap total assets. Kualitas aset mengukur proporsi aset yang manfaat di masa depan kurang pasti terhadap total aset. AQI adalah rasio kualitas aset tahun t terhadap kualitas aset tahun lalu. AQI lebih besar daripada 1 mengindikasikan perusahaan menangguhkan mengakui beban operasional dengan cara mengkapitaliasi pengeluaran operasional sebagai aset.

- Sales growth index (SGI)

SGI adalah rasio penjualan tahun $t$ dengan penjualan tahun sebelumnya. Perusahaan yang melakukan rekayasa diperkirakan memiliki pertumbuhan penjualan yang lebih lambat.

- Depreciation index (DEPI).

DEPI adalah rasio tingkat depresiasi tahun t-1 dan tingkat depresiasi tahun t. Tingkat depresiasi adalah beban depresiasi dibagi jumlah beban depresiasi dan net PPE. DEPI lebih besar daripada 1 mengindikasikan bahwa tarif depresiasi diturunkan. Hal ini meningkatkan kemungkinan perusahaan telah melakukan revisi masa manfaat aset tetap menjadi lebih panjang atau mengadopsi metode baru yang menghasilkan beban penyusutan lebih kecil.

- Sales, general, and administrative expenses index (SGAI)

SGAI adalah rasio beban penjualan, beban umum, dan beban administrasi terhadap penjualan tahun $\mathrm{t}$ dibandingkan dengan rasio serupa tahun lalu. Beneish (1999) berpendapat bahwa SGAI berhubungan positif dengan potensi rekayasa.

- Leverage index (LVGI)

LVGI adalah rasio total utang terhadap total aset tahun $t$ dibandingkan dengan rasio serupa tahun sebelumnya. LVGI lebih besar daripada 1 mengindikasikan kenaikan leverage.

- Total accruals to total assets (TATA).

TATA adalah perubahan modal kerja selain kas dikurangi depresiasi dibagi total aset.

TATA digunakan sebagai proksi sejauh mana kas mendasari laba yang dilaporkan.

Indeks-indeks keuangan yang digunakan beserta penghitungannya disajikan pada Tabel 1.

Tabel 1. Indeks-indekx Keuangan yang Digunakan pada Model Beneish M-Score

\begin{tabular}{|c|c|}
\hline Index & Rumus \\
\hline DSRI & Receivable $_{t} /$ Sales $_{t} /$ Receivable $_{t-1} /$ Sales $_{t-1}$ \\
\hline GMI & $\left(\right.$ Sales $_{t-1}-$ COGS $_{t-1} /$ Sales $\left._{t-1}\right) /$ Sales $_{t}-$ COGS $_{t} /$ Sales $_{t}$ \\
\hline AQI & $1-\left(\right.$ Current assets $_{t}+$ PPE $\left.\left._{t}\right)\right) /$ Total $_{\text {assets }} / 1-\left(\right.$ Current $_{\mathrm{t}}$ assets $\left._{\mathrm{t}-1}+\mathrm{PPE}_{\mathrm{t}-1}\right) /$ Total assets $_{\mathrm{t}-1}$ \\
\hline SGI & Salest $_{\mathrm{t}} /$ Sales $_{\mathrm{t}-1}$ \\
\hline DEPI & Depreciation $_{\mathrm{t}-1} /\left(\right.$ Depreciation $\left._{\mathrm{t}-1}+\mathrm{PPE}_{\mathrm{t}-1}\right) /$ Depreciation $_{\mathrm{t}} /\left(\right.$ Depreciation $\left._{\mathrm{t}}+\mathrm{PPE}_{\mathrm{t}}\right)$ \\
\hline SGAI & Sales, general, and adm. expenset/Sales ${ }_{t} /$ Sales, general, and adm. expense $e_{t-1} / S S_{l e s}-1$ \\
\hline LVGI & $\left(\mathrm{LTD}_{\mathrm{t}}+\right.$ Current liabilities $\left._{\mathrm{t}}\right) /$ Total $_{\text {assets }} /$ (LTD $_{\mathrm{t}-1}+$ Current liabilities $\left._{\mathrm{t}-1}\right) /$ Total $_{\text {assets }} \mathrm{t}_{\mathrm{t}-1}$ \\
\hline TATA & $\begin{array}{l}\triangle \text { Current assets }_{\mathrm{t}}-\triangle \mathrm{Cash}_{\mathrm{t}}-\left(\triangle \text { Current liabilities }_{\mathrm{t}}-\triangle \text { Current maturities of } \mathrm{LTD}_{\mathrm{t}}-\triangle \text { Income }\right. \\
\left.\text { tax payable }{ }_{\mathrm{t}}\right)- \text { Depreciation } \& \text { amortization }_{\mathrm{t}} / \text { Total assets }\end{array}$ \\
\hline
\end{tabular}

Sumber: Beneish (1999)

Model yang digunakan oleh Beneish untuk mendeteksi rekayasa laporan keuangan adalah: MScore $=-4.84+0.92 *$ DSRI $+0.528 *$ GMI $+0.404 *$ AQI $+0.892 *$ SGI $0.115 *$ DEPI $-0.172 *$ SGAI + 4.679*TATA - 0.327*LEVI (Maccarthy, 2017). Menurut Warshavsky (2012) sebagaimana 


\section{JURNALKU}

Volume 1 No. 4, Desember 2021

dikutip oleh Maccarthy (2017) nilai M-Score yang lebih besar daripada -2,22 mengindikasikan laporan laba rugi dan laporan posisi keuangan telah direkayasa.

\section{HASIL DAN PEMBAHASAN}

Data laporan posisi keuangan dan laporan laba rugi Rekind diolah menggunakan aplikasi Microsoft Excel. Hasil perhitungan indeks-indeks yang digunakan dalam Beneish MScore untuk tahun 2018 disajikan pada Tabel 2.

Tabel 2. Nilai Beneish M-Score Rekind Tahun 2018

\begin{tabular}{cccc}
\hline Item & Nilai & Bobot & Nilai x Bobot \\
\hline DSRI & 0,688 & 0,920 & 0,633 \\
\hline GMI & 1,376 & 0,528 & 0,726 \\
\hline AQI & 0,989 & 0,404 & 0,399 \\
\hline SGI & 1,367 & 0,892 & 1,220 \\
\hline DEPI & 1,019 & 0,115 & 0,117 \\
\hline SGAI & 0,334 & $-0,172$ & $-0,058$ \\
\hline LVGI & 1,070 & $-0,327$ & $-0,350$ \\
\hline TATA & 0,141 & 4,679 & 0,662 \\
\hline Konstanta & & & $-4,840$ \\
\hline Beneish M-Score & & & $-1,490$
\end{tabular}

Sumber: (Laporan Tahunan Rekind, 2018), diolah

Laporan Keuangan Rekind tahun 2018 mendapat nilai Beneish M-Score -1,49. Nilai ini lebih besar daripada nilai patokan, -2,22, sehingga dapat disimpulkan bahwa terdapat kemungkinan laporan laba rugi dan laporan posisi keuangan Rekind tahun buku 2018 telah direkayasa. Temuan ini sejalan dengan temuan Y. A. Nugroho (2017) bahwa salah satu cara yang dilakukan oleh perusahaan untuk menutupi kondisi perusahaan yang kurang baik adalah dengan merekayasa laporan keuangan. Temuan ini juga sejalan dengan temuan Haq et al (2017) bahwa integritas laporan keuangan dipengaruhi secara negatif oleh permasalahan keuangan. Beberapa informasi yang diberikan oleh indeks-indeks keuangan yang diterapkan pada model iniadalah sebagai berikut:

- Days' sales in receivales index (DSRI)

DSRI merupakan perbandingan antara rasio piutang/pendapatan tahun 2018 dengan rasio serupa tahun 2017. Rasio ini mengukur apakah piutang dan pendapatan proporsional atau tidak pada dua tahun yang berurutan. Menurut Maccarthy (2017) berdasarkan nilai ratarata DSRI perusahaan perekayasa dan non-perekayasa yang menjadi sampel penelitian Beneish (1999), nilai DSRI 1,031 atau kurang mengindikasikan bahwa akun-akun yang terkait DSRI tidak direkayasa dan nilai 1,465 atau lebih mengindikasikan bahwa akun-akun yang terkait dengan DSRI telah direkayasa. Nilai DSRI Rekind tahun 2018 sebesar 0,688. Dengan demikian dapat disimpulkan bahwa akun-akun piutang dan pendapatan Rekind tahun 2018 diperkirakan tidak direkayasa.

- Gross margin index (GMI)

GMI diukur dengan membandingkanan laba kotor tahun 2017 terhadap laba kotor tahun 2018. GMI Rekind tahun 2018 sebesar 1,376. Menurut pendapat Harrington (2005) sebagaimana dikutip oleh Maccarthy (2017) nilai GMI 1,041 atau lebih rendah mengindikasikan bahwa laba kotor periode saat ini tidak direkayasa tetapi nilai 1,193 atau lebih tinggi menunjukkan bahwa laba kotor perusahaan direkayasa. Berdasarkan kriteria ini dapat disimpulkan bahwa GMI Rekind tahun 2018 terindikasi telah direkayasa. Untuk 


\section{JURNALKU}

Volume 1 No. 4, Desember 2021

analisis lebih lanjut, perlu dicermati data-data pendapatan, harga pokok pendapatan, dan laba kotor tahun 2018 dan 2017 yang disajikan pada Tabel 3.

Tabel 3. Analisis GMI Rekind Tahun 2018

\begin{tabular}{ccccc}
\hline Akun & $\begin{array}{c}\mathbf{2 0 1 8} \text { (juta } \\
\text { rupiah) }\end{array}$ & $\begin{array}{c}\mathbf{2 0 1 7} \text { (juta } \\
\text { rupiah) }\end{array}$ & $\begin{array}{c}\text { Selisih (juta } \\
\text { rupiah) }\end{array}$ & $\begin{array}{c}\text { Selisih (juta } \\
\text { rupiah) }\end{array}$ \\
\hline Pendapatan & 4.914 .923 & 3.594 .431 & 1.320 .492 & $36,74 \%$ \\
\hline Beban Pokok Pendapatan & 4.105 .942 & 2.780 .610 & 1.325 .332 & $47,66 \%$ \\
\hline Laba Kotor & 808.981 & 813.821 & -4.840 & $-0,59 \%$
\end{tabular}

Sumber: (Laporan Tahunan PT Rekayasa Industri, 2018), diolah

Pada Tabel 3 terlihat kenaikan pendapatan Rekind dari Rp3,6 triliun pada tahun 2017 menjadi Rp4,9 triliun di tahun 2018. Terdapat kenaikan pendapatan sebesar Rp1,3 triliun atau sebesar 36,74\% dari pendapatan tahun 2017. Namun, beban pokok pendapatan mengalami kenaikan yang lebih besar, dari Rp2,8 triliun di tahun 2017 menjadi Rp4,1 triliun di tahun 2018. Terdapat kenaikan sebesar Rp1,3 triliun atau sebesar 47,66\% dari beban pokok pendapatan tahun 2017. Persentase kenaikan beban pokok pendapatan jauh lebih tinggi daripada persentase kenaikan pendapatan. Hal ini menjadi penyebab laba kotor turun dari Rp813,8 miliar di tahun 2017 menjadi Rp809 miliar di tahun berikutnya. Terdapat penurunan laba kotor sebesar Rp4,8 miliar atau sebesar 0,59\% dari laba kotor tahun 2017. Penurunan laba kotor ini dikarenakan penambahan biaya pada proyek Pusri 2B dan penurunan kontribusi pendapatan dari proyek Banggai Ammonia Plant (Laporan Tahunan PT Rekayasa Industri, 2018).

- Aset quality index (AQI)

AQI diukur dengan perbandingan kualitas aset tahun 2018 terhadap kualitas aset tahun 2017. Kualitas aset adalah perbandingan noncurrent assets selain property, plant, and equipment (PPE) terhadap total aset. Rasio kualitas aset mengukur proporsi aset yang manfaat di masa depan kurang pasti. AQI Rekind tahun 2018 sebesar 0,989. Berdasarkan nilai rata-rata AQI perusahaan perekayasa non-perekayasa yang menjadi sampel penelitian Beneish (1999) nilai AQI di bawah 1,039 adalah indikasi aset tidak lancar tidak direkayasa dan nilai di atas 1,254 mengindikasikan bahwa aset tidak lancar telah direkayasa. Dengan demikian dapat disimpulkan bahwa menurut Beneish M-Score tidak terdapat indikasi rekayasa nilai noncurrent assets selain property, plant, and equipment (PPE) dan total assets.

- Sales growth index (SGI)

SGI diukur dengan membagi penjualan tahun 2018 dengan penjualan tahun 2017. SGI Rekind tahun 2018 sebesar 1,376. Menurut Maccarthy (2017) berdasarkan nilai rata-rata DSRI perusahaan perekayasa dan non-perekayasa yang menjadi sampel penelitian Beneish (1999) nilai SGI 1,134 atau kurang adalah indikasi pendapatan tidak direkayasa dan nilai di atas 1,607 mengindikasikan bahwa pendapatan telah direkayasa. Nilai SGI Rekind berada di "grey area", tidak terindikasi direkayasa atau tidak direkayasa.

- Depreciation index (DEPI).

DEPI adalah perbandingan tingkat depresiasi tahun 2017 dan tingkat depresiasi tahun 2018. Tingkat depresiasi dihitung dengan membagi beban depresiasi dengan jumlah beban depresiasi dan net PPE. Menurut Maccarthy (2017) berdasarkan nilai rata-rata DEPI perusahaan perekayasa dan non-perekayasa yang menjadi sampel penelitian Beneish (1999) nilai DEPI 1,001 atau lebih rendah merupakan indikasi bahwa DEPI tidak direkayasa dan skor di atas 1,077 adalah indikasi bahwa nilai aset telah direvaluasi atau masa manfaat aset tetapa telah diperpanjang. DEPI Rekind tahun 2018 sebesar 1,019. 
Dengan demikian nilai DEPI Rekind berada di "grey area", tidak terindikasi direkayasa atau tidak direkayasa.

- Sales, general, and administrative expenses index (SGAI)

SGAI merupakan pembagian rasio beban penjualan, beban umum, dan beban administrasi terhadap penjualan tahun t dengan rasio serupa tahun sebelumnya. SGAI Rekind tahun 2018 sebesar 0,334. Mengikuti pendapat Beneish (1999) bahwa SGAI berhubungan positif dengan potensi rekayasa. Dengan kata lain perusahaan dengan nilai SGAI kecil memiliki kemungkinan kecil untuk melakukan rekayasa. Dengan demikian dapat disimpulkan bahwa menurut Beneish M-Score kecil kemungkinan telah nilai sales, general, and administrative expense Rekind tahun 2018 telah di rekayasa.

- Leverage index (LVGI)

LVGI diukur dengan membandingkan rasio total utang terhadap total aset tahun 2018 dengan rasio serupa 2017. Berdasarkan nilai rata-rata LVGI perusahaan perekayasa dan non-perekayasa yang menjadi sampel penelitian Beneish (1999) nilai LVGI di bawah 1,037 adalah indikasi akun-akun terkait LVGI tidak direkayasa dan nilai di atas 1,111 mengindikasikan bahwa akun-akun terkait LVGI telah direkayasa. Nilai LVGI Rekind tahun 2018 sebesar 1,070 berada di "grey area", tidak terindikasi direkayasa atau tidak direkayasa.

- $\quad$ Total accruals to total assets (TATA).

TATA adalah rasio perubahan modal kerja selain kas dikurangi depresiasi dan total aset. TATA merupakan proksi sejauh mana kas mendasari laba yang dilaporkan. TATA Rekind tahun 2018 sebesar 0,141. Menurut Maccarthy (2017) berdasarkan nilai rata-rata SGAI perusahaan perekayasa non-perekayasa yang menjadi sampel penelitian Beneish (1999) nilai 0,018 atau kurang adalah indikasi akun-akun terkait TATA tidak direkayasa dan nilai 0,031 atau lebih merupakan indikasi bahwa akun-akun terkait TATA telah direkayasa. Berdasarkan kriteria ini dapat disimpulkan bahwa akun-akun terkait TATA Rekind tahun 2018 telah direkayasa. Untuk analisis lebih lanjut, perlu dicermati data-data perubahan modal kerja tahun 2018 yang disajikan pada Tabel 4.

Penjelasan atas kenaikan akun-akun tersebut yang melebihi $33,3 \%$ di catatan atas laporan keuangan sebagai berikut:

- Penurunan piutang lain-lain sebesar Rp73,79 miliar atau 48,58\% dibandingkan pada tahun 2017 terjadi karena penurunan piutang lain-lain pihak berelasi sebesar Rp19,42 miliar atau $50,64 \%$ dan piutang lain-lain pihak ketiga sebesar Rp54,37 miliar atau 47,88\%.

- Piutang retensi mengalami penurunan Rp70,66 miliar atau 50,27\% seiring dengan penurunan piutang retensi pihak berelasi sebesar Rp60,77 miliar atau 50,96\% dan piutang retensi pihak ketiga sebesar Rp9,89 miliar atau 46,40\%.

- Pekerjaan dalam penyelesaian kontrak konstruksi kepada pemberi kerja mengalami pertumbuhan Rp752,46 miliar atau 43,44\% dibandingkan pada tahun 2017 sebesar Rp1,73 triliun menjadi sebesar Rp2,48 triliun.

- Uang muka mengalami pertumbuhan Rp32,26 miliar atau 36,52\% terutama disebabkan oleh pertumbuhan uang muka kontrak sebesar Rp21,43 miliar atau 48,90\%, diikuti dengan pertumbuhan uang muka pembelian dan uang muka site office.

Tabel 4. Perubahan Modal Kerja Rekind Tahun 2018

\begin{tabular}{|c|c|c|c|c|}
\hline Akun & $\begin{array}{c}2018 \text { (juta } \\
\text { rupiah) }\end{array}$ & $\begin{array}{c}2017 \text { (juta } \\
\text { rupiah) }\end{array}$ & $\begin{array}{c}\text { Selisih } \\
\text { (juta } \\
\text { rupiah) }\end{array}$ & $\begin{array}{c}\text { Persentase } \\
\text { Selisih }\end{array}$ \\
\hline Kas dan Setara Kas & 1.115 .444 & 1.181 .104 & -65.660 & $-5,56 \%$ \\
\hline Piutang Usaha & 990.245 & 917.774 & 72.471 & $7,90 \%$ \\
\hline Piutang Lain-lain & 78.107 & 151.897 & -73.790 & $-48,58 \%$ \\
\hline
\end{tabular}


Volume 1 No. 4, Desember 2021

\begin{tabular}{lcccc}
\hline \multicolumn{1}{c}{ Akun } & $\begin{array}{c}\text { 2018 (juta } \\
\text { rupiah) }\end{array}$ & $\begin{array}{c}\text { 2017 (juta } \\
\text { rupiah) }\end{array}$ & $\begin{array}{c}\text { Selisih } \\
\text { (juta } \\
\text { rupiah) }\end{array}$ & $\begin{array}{c}\text { Persentase } \\
\text { Selisih }\end{array}$ \\
\hline Piutang Retensi & 69.904 & 140.559 & -70.655 & $-50,27 \%$ \\
\hline $\begin{array}{l}\text { Kontrak Konstruksi-Tagihan Bruto } \\
\text { Kepada Pemberi Kerja }\end{array}$ & 2.484 .814 & 1.732 .350 & 752.464 & $43,44 \%$ \\
\hline Uang Muka & 120.605 & 88.342 & 32.263 & $36,52 \%$ \\
\hline Beban Dibayar di Muka & 9.347 & 2.893 & 6.454 & $223,09 \%$ \\
\hline Pajak Dibayar di Muka & 448.448 & 342.675 & 105.773 & $30,87 \%$ \\
\hline $\begin{array}{l}\text { Bagian Lancar atas Aset Keuangan } \\
\text { dari Konsesi Jasa }\end{array}$ & 188.892 & 134.197 & 54.695 & $40,76 \%$ \\
\hline Persediaan & 12.694 & - & 12.694 & \\
\hline Total Aset Lancar & 5.518 .500 & 4.691 .791 & 826.709 & $17,62 \%$ \\
\hline $\begin{array}{l}\text { Bagian Lancar Liabilitas Jangka } \\
\text { Panjang }\end{array}$ & 352.910 & 135.614 & 217.296 & $160,23 \%$ \\
\hline Total Liabiitas Jangka Pendek & 9.921 .556 & 8.202 .478 & 1.719 .078 & $20,96 \%$ \\
\hline Utang Pajak & 108.892 & 133.783 & -24.891 & $-18,61 \%$ \\
\hline Total Liabiitas Jangka Pendek & 9.921 .556 & 8.202 .478 & 1.719 .078 & $20,96 \%$ \\
\hline
\end{tabular}

Sumber: (Laporan Tahunan PT Rekayasa Industri, 2018), diolah

- Beban dibayar dimuka mengalami pertumbuhan Rp6,45 miliar atau 223,09\% namun tidak ada rincian.

- Bagian Lancar atas Aset Keuangan dari Konsesi Jasa mengalami pertumbuhan Rp54,70 miliar atau 40,76\% namun tidak ada rincian lebih lanjut.

- Persediaan tidak ada rincian.

- Bagian Lancar Liabilitas Jangka Panjang tidak ada rincian lebih lanjut.

\section{PENUTUP}

\section{Simpulan}

Berdasarkan model Beneish M-Score, laporan laba rugi dan laporan posisi keuangan Rekind tahun 2018 terindikasi telah direkayasa. Hal ini disimpulkan dari nilai Beneish M-Score sebesar -1,49, lebih besar daripada nilai acuan -2,22. Simpulan ini sejalan dengan temuan Y. A. Nugroho (2017) bahwa salah satu cara yang dilakukan oleh perusahaan untuk memoles kondisi perusahaan yang kurang baik adalah dengan merekayasa laporan keuangan. Simpulan ini juga sejalan dengan temuan Haq et al (2017) bahwa integritas laporan keuangan dipengaruhi secara negatif oleh permasalahan keuangan. Terdapat dua indeks yang terindikasi telah direkayasa yaitu GMI dan TATA; tiga rasio terindikasin tidak direkayasa yaitu DSRI, AQI, dan SGAI; dan tiga rasio yang berada pada "grey area" yaitu SGI, DEPI, dan LVGI.

Nilai GMI, rasio laba kotor tahun 2017 terhadap laba kotor tahun 2018, sebesar 1,376 mengindikasikan bahwa akun-akun terkait GMI telah direkayasa. Pendapatan Rekind tahun 2018 naik sebesar Rp1,32 triliun $(36,74 \%)$ namun, beban pokok pendapatan mengalami kenaikan yang lebih besar, Rp1,33 triliun (47,66\%). Kenaikan ini disebabkan oleh penambahan biaya pada proyek Pusri 2B. Hal ini menjadikan laba kotor turun Rp4,84 miliar (0,59\%). Nilai TATA, rasio perubahan modal kerja selain kas dikurangi depresiasi dan total aset, sebesar 0,141 mengindikasikan akun-akun yang terkait TATA telah direkayasa. Piutang lain-lain turun Rp73,8 miliar (48,58\%). Piutang retensi turunan Rp70,7 miliar (50,27\%). Pekerjaan dalam penyelesaian kontrak konstruksi kepada pemberi kerja mengalami naik Rp752,5 miliar $(43,44 \%)$. Uang muka naik Rp32,3 miliar $(36,52 \%)$ terutama disebabkan oleh kenaikan uang muka kontrak sebesar Rp21,4 miliar (48,90\%). Beban dibayar dimuka naik Rp6,5 miliar (223,09\%). Bagian lancar atas aset keuangan dari konsesi jasa naik Rp54,7 miliar (40,76\%). 


\section{JURNALKU}

Volume 1 No. 4, Desember 2021

Nilai DSRI, rasio antara piutang/pendapatan tahun tahun 2018 dengan rasio serupa tahun lalu, sebesar 0,688 mengindikasikan bahwa piutang dan pendapatan Rekind tahun 2018 tidak direkayasa. Nilai AQI, rasio kualitas aset tahun 2018 terhadap kualitas aset tahun 2017, sebesar 0,989 mengindikasikan bahwa tidak terdapat rekayasa nilai noncurrent assets selain property, plant, and equipment (PPE) dan total assets. Nilai SGAI, rasio beban penjualan, beban umum, dan beban administrasi terhadap penjualan tahun $\mathrm{t}$ dengan rasio serupa tahun sebelumnya, sebesar 0,334 mengindikasikan sales, general, and administrative expense tidak direkayasa.

Nilai SGI, rasio penjualan tahun 2018 dan penjualan tahun 2017, sebesar 1,367 berada di "grey area". Nilai DEPI, rasio beban depresiasi /jumlah beban depresiasi dan net PPE tahun 2017 dan rasio serupa tahun 2018, sebesar 1,019 berada di "grey area". Nilai LVGI, rasio total utang terhadap total aset tahun 2018 dibandingkan dengan rasio serupa tahun lalu, sebesar 1,070 berada di "grey area".

\section{Saran}

Penelitian selanjutnya bisa dilakukan untuk menguji apakah laporan laba rugi dan laporan posisi keuangan PT Rekind tahun 2018 telah direkayasa atau tidak dengan membandingkan laporan keuangan 2018 dengan laporan keuangan komparatif tahun 2019. Dari perbandingan tersebut akan terlihat apakah nilai akun-akun pada laporan keuangan tahun 2018 mengalami restatement atau tidak pada laporan komprehensif tahun 2019.

\section{DAFTAR PUSTAKA}

Alfian, F., \& Triani, N. N. A. (2018). Fraudulent Financial Reporting Detection Using Beneish M-Score Model in Public Companies in 2012-2016. Asia Pacific Fraud Journal, 4(1).

Beneish, M. D. (1999). The Detection of Earnings Manipulation. Financial Analysts Journal, 55(5). https://doi.org/10.2469/faj.v55.n5.2296

Haq, F. R. G., Suzan, L., \& Musllih, M. (2017). Pengaruh Kepemilikan Manajerial dan Financial Distress terhadap Integritas Laporan Keuangan. Assets: Jurnal Ekonomi, Manajemen Dan Akuntansi, 7(1), 41-55.

Hugo, J. (2019). Efektivitas Model Beneish M-Score Dan Model F-Score Dalam Mendeteksi Rekayasa Laporan Keuangan. Jurnal Muara Ilmu Ekonomi Dan Bisnis, 3(1). https://doi.org/10.24912/jmieb.v3i1.2296

Laporan Tahunan PT Rekayasa Industri. (2018). http://www.rekayasa.com/wpcontent/uploads/2020/01/AR2018.pdf

Maccarthy, J. (2017). Using Altman Z-score and Beneish M-score Models to Detect Financial Fraud and Corporate Failure: A Case Study of Enron Corporation. International Journal of Finance and Accounting, 6(6).

Nugroho, B. (2020). Potensi Rekayasa Pendapatan Menggunakan Model Beneish M-Score, Studi Kasus pada Laporan Keuangan PT Garuda Indonesia Tbk., Tahun 2017-2018. Jurnal Online Insan Akuntan, 5(1). https://doi.org/10.51211/joia.v5i1.1321

Nugroho, Y. A. (2017). Pengaruh Tingkat Akrual Diskresioner dan Kesulitan Keuangan Terhadap Kemungkinan Terjadinya Rekayasa Laporan Keuangan. Universitas Gadjah Mada.

Özcan, A. (2018). The Use of Beneish Model in Forensic Accounting Accunting: Evidence from Turkey. Journal of Applied Economics and Business Research, 8(1).

Sianturi, H. R. (2020a). Boy dan Erick Terseret Uang Rekayasa. https://magazine.gatra.com/detail/news/469050/laporan utama/boy-dan-erick-terseretuang-rekayasa?lang=ID

Sianturi, H. R. (2020b). No Title. https://magazine.gatra.com/detail/news/469050/laporan utama/boy-dan-erick-terseret-uang-rekayasa?lang=ID 